\title{
Effect of 2,4-Dichlorophenoxy Acetic Acid on Antioxidant Systems in a Non-Target Plant (Zea mays L.)
}

\author{
Hanan Mahmoud Abou-Zeid ${ }^{*}$, Salwa Ahmed Abdel-Latif ${ }^{\mathbf{2}}$ and Ghada Saber Mohamed Ismail ${ }^{1}$ \\ ${ }^{1}$ Botany and Microbiology Department, Faculty of Science, Alexandria University, Alexandria, Egypt. \\ ${ }^{2}$ Biology and Geology Department, Faculty of Education, Alexandria University, Egypt.
}

\begin{abstract}
This work aimed to study the impact of various concentrations $\left(2,5,10 \mathrm{mg} \mathrm{L}^{-1}\right)$ of the herbicide 2,4-dichlorophenoxy acetic acid (2,4-D) on fresh and dry biomasses, photosynthetic pigments, quantum yield of PSII (Fv/Fm) and oxidative stress parameters of 28-day old Zea mays leaves. Foliar application of a low dose of 2,4-D significantly promoted the growth biomarkers, whereas, the high doses induced severe disturbances and reduced the growth attributes. In addition, over-accumulation of hydrogen peroxide $\left(\mathrm{H}_{2} \mathrm{O}_{2}\right)$ and lipid peroxidation (MDA) were recorded and that was accompanied with a significant increase in activity of superoxide dismutase (SOD), catalase (CAT) and glucose-6-phosphate dehydrogenase (G6PDH). Otherwise there was a significant decline in ascorbate peroxidase (APx), guiacol peroxidase (GPX), glutathione peroxidase (GSHPx) and glutathione reductase (GR). Moreover, a significant decline of the reduced glutathione (GSH) and ascorbic acid (AsA) contents, glutathione redox potential (GSH/GSSG), NADPH and $\mathrm{NADPH} / \mathrm{NADP}^{+}$ratios were recorded. These observations might indicate that high doses of 2,4-D caused a menace to non-target plants through the disruption of antioxidant systems.
\end{abstract}

Keywords: Antioxidant enzymes, glutathione, hydrogen peroxide, maize, photosynthetic pigments.

\section{INTRODUCTION}

The 2,4-dichlorophenoxyacetic acid (2,4-D) is a general herbicide used to manage a variety of weeds with broad leaves. All over the world, it is the third most commonly applied herbicide and is still utilized in Egypt. There is a contradicted thought concerning its half-life and its toxicity in the environment (Samir et al., 2015). The wide use of herbicides in intensive agricultural practice has conveyed out serious environmental and health effects. They cause abiotic stress on plants, so they cause phytotoxicity, growth decline, and plant metabolism variations by production of reactive oxygen species (ROS) (Cobb and Reade, 2010).

Highly reactive ROS is causing lipid peroxidation, thus damaging the cell membranes, the disturbance of photosynthesis and numerous protection mechanisms (Kruse et al., 2006). 2,4-D is an artificial auxin that is similar in its effect to a natural auxin indole acetic acid (IAA), though, it has long duration owing to their high constancy in the plant and its degradation or inactivation is less than natural auxins in the plant. One of its numerous analogues is well-known in initiating the expression of auxin responsive genes particularly those concerned in ethylene and abscisic acid synthesis; both compounds that are well known to induce the production of ROS, which are accountable for mounting the oxidative stress (Pazmiño et al., 2012; Goggin et al., 2016). Regrettably, 2, 4-D has non-specific weed targets (Zabaloy and Gómez, 2014); it may reduce growth, incite reproductive problems, create changes in appearance and might cause the nontarget species death. Islam et al., (2017) reported that short-term exposure to high concentrations of 2,4-D could stimulate DNA damages in the Phaseolus vulgaris and Zea mays seedlings.

The over production of ROS was induced by biotic and abiotic factors (Czarnocka and Karpinski, 2018).
The defense system of plant executes scavenge ROS and reinstate cellular homeostasis. To balance the ROS production and detoxification, plants possess antioxidant-defense systems comprises enzymatic and nonenzymatic mechanisms (Skiba and Wolf, 2017). Alterations in enzymatic antioxidants include superoxide dismutase (SOD), catalase (CAT), ascorbate peroxidase (APx), guaiacol peroxidase (GPx), glutathione peroxidase (GSHPx) and glutathione reductase (GR) (Agostinetto et al., 2016; Harre et al., 2018). Nonenzymatic antioxidant compounds comprise phenolic compounds, glutathione, ascorbate (AsA), tocopherol, and proline (Gill and Tuteja, 2010). The ascorbateglutathione (AsA-GSH) cycle has been considered as one of the most important antioxidant pathways (Noctor and Foyer, 1998).

The major pathway of the production of NADPH is the oxidative pentose phosphate pathway (OPPP) which is significant for biosynthesis and redox steadiness in the plant cells. The majority of NADPH in the cytoplasm is produced by G6PDH and 6-phosphogluconate dehydrogenase (Corpas and Barroso, 2018). G6PDH is essential for maintaining GSH and NADPH homeostasis (Wang et al., 2019).

Maize (Zea mays L.) is considered as one of the most imperative cereal crops in the globe as it's highly used as food and fodder. The yield of maize is greatly affected by weeds in the field. Strategies efforts have been performed to limit the harmful effects of weeds growing with crop plants. The different defence mechanisms of plants against oxidative stress caused by herbicides might be useful in classifying such herbicides into a product with lower or higher ability of oxidative stress in crops (Nohatto et al., 2016).This work aimed to assess the effects of application of different 2,4-D concentrations on growth biomarkers, some physiological attributes and the antioxidant defense system of maize plants. 


\section{MATERIALS AND METHODS}

Maize (Zea mays L. cv. Nevertity) grains were purchased from the National Research Center, ElDokki, Giza, Egypt. Grains were subjected to surface sterilization with $0.1 \%$ sodium hypochlorite solution for $5 \mathrm{~min}$ and then washed several times with distilled water. In plastic pots (12 cm in diameter, $17 \mathrm{~cm}$ length) containing soil mixture of clay and sand (1:2 W/W), the grains were sown. Two sets of pots (in triplicates) were placed at natural environmental conditions (photoperiod of $16 \mathrm{~h} / 8 \mathrm{~h}$ light/dark, $31 / 28 \pm 2{ }^{\circ} \mathrm{C}$ day/night temperature; light intensity PPFD, $23 \mu \mathrm{mol} \mathrm{m} \mathrm{s}^{-2}$ ) for 14 days, irrigated every two days intervals using strength one tenth of Hoagland's nutrient solution (Hoagland and Arnon, 1950) along the experimental period to field capacity. At the day 15 from sowing the first set of pots was sprayed with distilled water and considered as a control and the other set was sprayed with 2,4-D solution $\left(2,5\right.$ and $\left.10 \mathrm{mg} \mathrm{L}^{-1}\right)$. The foliar spray was applied two times at the day 15 and the day 22 from sowing. After 28 days, similar plants were harvested, washed thoroughly from adhering soil particles, gently plotted, and the leaves were quickly saved for estimation of the various growth parameters and chemical analyses.

\section{Plant growth parameters}

The leaves were cautiously cleaned by dist. $\mathrm{H}_{2} \mathrm{O}$, dried by tissue paper and weighted for fresh weight (FW) estimation, and for dry weight (DW) the leaves were kept in oven for $72 \mathrm{~h}$ at $70^{\circ} \mathrm{C}$.

\section{Photosynthetic pigments content}

The photosynthetic pigments were determined according to the method described by Moran and Porath (1980) using N,N-dimethyl formamide (DMF), total carotenoid content was calculated according to Wellburn (1994) in related to leaf weight.

\section{Measurement of the maximum quantum efficiency of PSII (Fv/Fm)}

The ratio of the maximum quantum efficiency of PSII (Fv/Fm) was detected following the method described by Branquinho et al., (1997) using OS-30P pulse modulated (Opti-sciences, Hudson, USA) chloro-phyll fluorimeter. Before every measurement leaves were dark-adapted for $30 \mathrm{~min}$ with leaf-clips.

Determination of hydrogen peroxide and malondialdehyde contents

Levels of hydrogen peroxide $\left(\mathrm{H}_{2} \mathrm{O}_{2}\right)$ were measured following the method of Sergiev et al., (1997). Malondialdehyde (MDA), the lipid peroxidation product was estimated according to method used by Buege and Aust (1978).

\section{Extraction and estimation of antioxidant enzymes activities}

Fresh leaves $(1 \mathrm{~g})$ were homogenized in ice cold 50 $\mathrm{mM}$ phosphate buffer $(\mathrm{pH} 7.5)$ containing $0.5 \mathrm{mM}$ EDTA with prechilled pestle and mortar. The homogenate was centrifuged at $10,000 \mathrm{xg}$ for $10 \mathrm{~min}$ at $4{ }^{\circ} \mathrm{C}$, then the supernatants were collected and used for determination the different enzyme activities. Superoxide dismutase (SOD, EC 1.15.1.1) activity was determined following the method described by Giannopolitis and Ries (1977) where its ability to inhibit the photo reduction of nitroblue tetrazolium (NBT) was measured. The activity of catalase (CAT, 1.11.1.6) was assayed following the technique of Zhang et al., (2005). Ascorbate peroxidase (APX, 1.11.1.11) activity was assayed according to the method of Boominathan and Doran (2002) following the reduction in absorbance at $290 \mathrm{~nm}$. The activity of guaiacol peroxidase (GPx, 1.11.1.7) was estimated following Urbanek et al., (1991) method. Glutathione reductase (GR, 1.6.4.2) activity was detected using the method of Goldberg and Spooner (1983). However, glutathione peroxidase (GSHPx 1.11.1.9) activity was measured as described by Elia et al., (2003)

\section{Extraction and analysis of ascorbate content and glutathione fractions}

Extraction of ascorbate (AsA) and glutathione was performed following the method mentioned by Gossett et al., (1994), and it was measured according to Zhang and Kirkham (1996). Reduced glutathione (GSH) and oxidized glutathione (GSSG) contents were assayed according to the methods of Griffith (1985).

\section{Extraction and determination of glucose-6-phos- phate dehydrogenase activity}

G6PDH (EC 1.1.1.49) extracted and assayed the activity spectrophotometrically at $30^{\circ} \mathrm{C}$ by monitoring the decrease of $\operatorname{NADP}^{+}\left(\varepsilon=6.22 \mathrm{mM}^{-1} \mathrm{~cm}^{-1}\right)$ at 340 $\mathrm{nm}$ according to Sgherri et al., (2002).

\section{Extraction and determination of NADP $^{+}$and NADPH}

For HPLC analysis using PerkinElmer series 200 LC and UV/VIS detector 200 LC, USA system set with a 5- $\mu \mathrm{m}$ column (Spheri-5 RP-18; 220×4.6 mm; Brownlee), samples $(0.3 \mathrm{~g})$ were extracted either by acid $(0.6$ $\mathrm{M}$ perchloric acid) for nicotinamide adenine dinucleotide phosphate $\left(\mathrm{NADP}^{+}\right)$measurement or alkaline (0.5 M potassium hydroxide) extraction for measureement of NADPH. Centrifugation was performed for the extract at $10,000 \times \mathrm{g}$ at $4^{\circ} \mathrm{C}$ for $10 \mathrm{~min}$ followed by neutralization by either $0.5 \mathrm{M} \mathrm{KOH}$ or $1 \mathrm{M} \mathrm{KH}_{2} \mathrm{PO}_{4}$ and centrifugation again at $10,000 \mathrm{xg}$ at $4{ }^{\circ} \mathrm{C}$ for $10 \mathrm{~min}$. Twenty $\mu \mathrm{l}$ of the supernatants were employed as declared by Caruso et al., (2004).

\section{Statistical analysis}

Duncan's multiple range tests by means of SPSS-20 were used for the results statistical analyses following Sokal and Rohlf (1995) method. Data were subjected to one-way ANOVA. Differences between treatment means were considered statistically significant at $p \leq 0.05$.

\section{RESULTS}

\section{Plant growth parameters}

Both fresh and dry biomasses of 28-day old maize leaves were significantly increased at $2 \mathrm{mg} \mathrm{L}^{-1} 2,4-\mathrm{D}$ treatment, the percentage of the increase was $25 \%$ and $33 \%$, respectively compared to control. On the other hand, mid (5 $\left.\mathrm{mg} \mathrm{L}^{-1}\right)$ and high $\left(10 \mathrm{mg} \mathrm{L}^{-1}\right)$ 2,4-D 
concentrations significantly decreased the biomass. The decrease in FW and DW of $10 \mathrm{mg} \mathrm{L}^{-1}$ sprayed leaves was about $63 \%$ and $56 \%$, respectively versus to control (Table 1).

Table (1): The effect of different concentrations of 2,4-D on fresh and dry weight (FW and DW), photosynthetic pigments content and quantum yield of PSII (Fv/Fm) in maize leaves.

\begin{tabular}{|c|c|c|c|c|c|c|c|}
\hline \multirow{2}{*}{$\begin{array}{c}\text { Treatment } \\
\left(\mathrm{mg} \mathrm{L}^{-1}\right)\end{array}$} & \multicolumn{2}{|c|}{ Biomass (mg plant ${ }^{-1}$ ) } & \multicolumn{2}{|c|}{$\begin{array}{c}\text { Chlorophyll content } \\
\left(\mu \mathrm{g} \mathrm{g}^{-1} \mathrm{FW}\right)\end{array}$} & \multirow{2}{*}{$\begin{array}{c}\text { Carot. } \\
\text { Content } \\
\left(\mu \mathrm{g} \mathrm{g}^{-1} \mathrm{FW}\right)\end{array}$} & \multirow{2}{*}{$\begin{array}{c}\text { Total } \\
\text { Pigment } \\
\text { content }\end{array}$} & \multirow[t]{2}{*}{ Fv/Fm } \\
\hline & FW & DW & Chl.a & Chl.b & & & \\
\hline $\mathbf{0}$ & $75 \pm 0.32^{\mathrm{a}}$ & $18 \pm 0.02^{\mathrm{a}}$ & $20.7 \pm 0.04^{\mathrm{a}}$ & $10.4 \pm 0.02^{\mathrm{a}}$ & $5.3 \pm 0.03^{\mathrm{a}}$ & $36.7 \pm 0.31^{\mathrm{a}}$ & $0.791 \pm 0.02^{\mathrm{a}}$ \\
\hline 2 & $94 \pm 0.51^{b}$ & $24 \pm 0.03^{b}$ & $25.6 \pm 0.04^{\mathrm{a}}$ & $13.8 \pm 0.02^{\mathrm{ab}}$ & $5.9 \pm 0.03^{\mathrm{a}}$ & $38.4 \pm 0.32^{\mathrm{a}}$ & $0.787 \pm 0.02^{\mathrm{a}}$ \\
\hline 5 & $57 \pm 0.22^{c}$ & $15 \pm 0.02^{c}$ & $13.0 \pm 0.06^{\mathrm{b}}$ & $7.6 \pm 0.05^{\mathrm{b}}$ & $3.3 \pm 0.01^{\mathrm{b}}$ & $23.9 \pm 0.22^{\mathrm{b}}$ & $0.704 \pm 0.03^{\mathrm{bc}}$ \\
\hline 10 & $28 \pm 0.23^{\mathrm{d}}$ & $8 \pm 0.02^{\mathrm{d}}$ & $7.2 \pm 0.03^{c}$ & $4.2 \pm 0.04^{\mathrm{c}}$ & $1.9 \pm 0.03^{\mathrm{c}}$ & $13.3 \pm 0.06^{\mathrm{c}}$ & $0.649 \pm 0.02^{\mathrm{c}}$ \\
\hline
\end{tabular}

Values are means \pm SD based on triplicate independent determinations. Different letters indicates significant difference as evaluated by Duncan's multiple range test.

\section{Photosynthetic pigments content}

There was a significant decrease in photosynthetic pigments content of high dose of 2,4-D-sprayed leaves in comparison to unsprayed ones (Table 1). In treatment using $10 \mathrm{mg} \mathrm{L}^{-1}$ - sprayed leaves, the decline in Chl.a, Chl.b and Carotenoid content was 65\%, 60\% and $64 \%$, respectively, compared to control. In addition, the decrease of total pigments content was associated with a decline in Fv/Fm values (Table 1).

\section{Hydrogen peroxide and malondialdehyde contents}

The oxidative stress was evaluated from the induction of $\mathrm{H}_{2} \mathrm{O}_{2}$ generation and lipoxygenation of plasma membranes, as indicated by increasing of MDA content (Figure 1). $\mathrm{H}_{2} \mathrm{O}_{2}$ and MDA contents in maize leaves sprayed with $5 \mathrm{mg} \mathrm{L}^{-1}$ or $10 \mathrm{mg} \mathrm{L}^{-1} 2$, 4-D significantly increased, whereas, those of $2 \mathrm{mg} \mathrm{L}^{-1}$ sprayed leaves insignificantly changed compared to control. The increase of the $\mathrm{H}_{2} \mathrm{O}_{2}$ and MDA accumulation in $10 \mathrm{mg} \mathrm{L}^{-1}$-sprayed leaves was 2.5 - and 3.3-fold of the control, respectively.

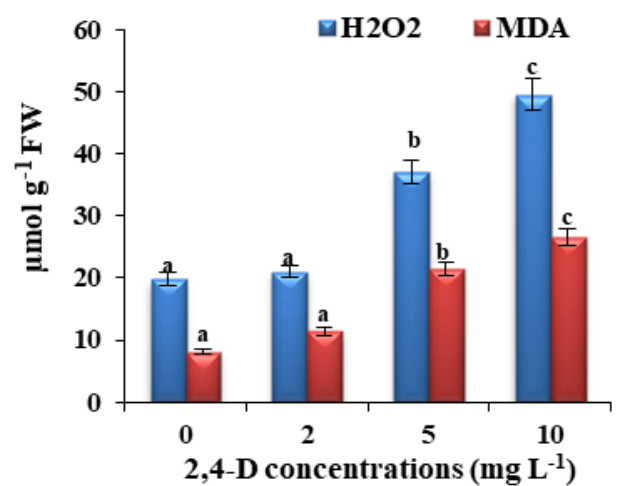

Figure (1): The effect of different concentrations of 2,4-D on hydrogen peroxide $\left(\mathrm{H}_{2} \mathrm{O}_{2}\right)$ and malondialdehyde (MDA) content in maize leaves. Values are means \pm SD based on triplicate independent determinations. Different letters means significant difference $(p \leq 0.05)$ as evaluated by Duncan's multiple range test.

\section{Antioxidant enzymes activities}

The SOD activity was significantly increased by increasing 2,4-D concentrations. The activity of SOD in $5 \mathrm{mg} \mathrm{L}^{-1}$ and $10 \mathrm{mg} \mathrm{L}^{-1}$-sprayed leaves were 4.1- and 6.6-times of controls, respectively, whereas, CAT activity was significantly increased up to $5 \mathrm{mg} \mathrm{L}^{-1} 2,4$ $\mathrm{D}$ level, then sharply declined at severe ones. There were significant increases of APx, GSHPx and GR activities of $2 \mathrm{mg} \mathrm{L}^{-1}$-sprayed leaves; which amounted to $40 \%, 28 \%$ and $33 \%$, respectively, with respect to the control plants. Conversely, at mid and sever 2,4-D levels the APx, GSHPx and GR activities in maize leaves were significantly decreased in comparison to non-sprayed plants. The decrease in these enzyme activities reached $45 \%, 62 \%$ and $73 \%$ in $10 \mathrm{mg} \mathrm{L}^{-1}$ sprayed leaves, respectively. On the other hand, the GPx activity in 2, 4-D-treated leaves was insignificantly changed (Figure 2).

\section{Ascorbate, glutathione fractions, NADPH and NADP $^{+}$contents}

Spraying maize leaves with mid and high 2,4-D concentrations significantly declined AsA content compared to control, while the low concentration had almost no effect (Table 2). Total glutathione (TG) and its reduced form (GSH), in the maize leaves, were significantly reduced with increasing 2,4-D concentrations, whereas the oxidized form (GSSG) was signifycantly increased in comparison to untreated leaves. At $10 \mathrm{mg} \mathrm{L}^{-1} 2,4-\mathrm{D}$, the decreases of TG and GSH contents were $28 \%$ and $56 \%$, respectively, compared to the control. These values were associated with an increase of GSSG content by $62 \%$ (Table 3 ).

In addition, the glutathione redox potential (GSH/GSSG) values in leaves were significantly decreased with increasing the concentrations of 2,4-D (Table 3). At 28 day of the experimental period, the GSH/GSSG in $5 \mathrm{mg} \mathrm{L}^{-1}$ and $10 \mathrm{mg} \mathrm{L}^{-1}$ 2, 4-D-treated leaves were 1.53 and 0.86 , respectively, compared to control leaves (3.17). It is shown that NADPH content and NADPH/NADP ${ }^{+}$ratio were significantly declined in $5 \mathrm{mg} \mathrm{L}^{-1}$ and $10 \mathrm{mg} \mathrm{L}^{-1}$ 2,4-D-treated leaves, while $\mathrm{NADP}^{+}$content increased compared to control ones. At $10 \mathrm{mg} \mathrm{L}^{-1}$ 2,4-D, the decreases of NADPH and $\mathrm{NADPH} / \mathrm{NADP}^{+}$ratio in the leaves were $58 \%$ and $73 \%$ compared to control, respectively. Simultaneously, an increase in the content of $\mathrm{NADP}^{+}$, reached $51 \%$ of the control, was recorded. 

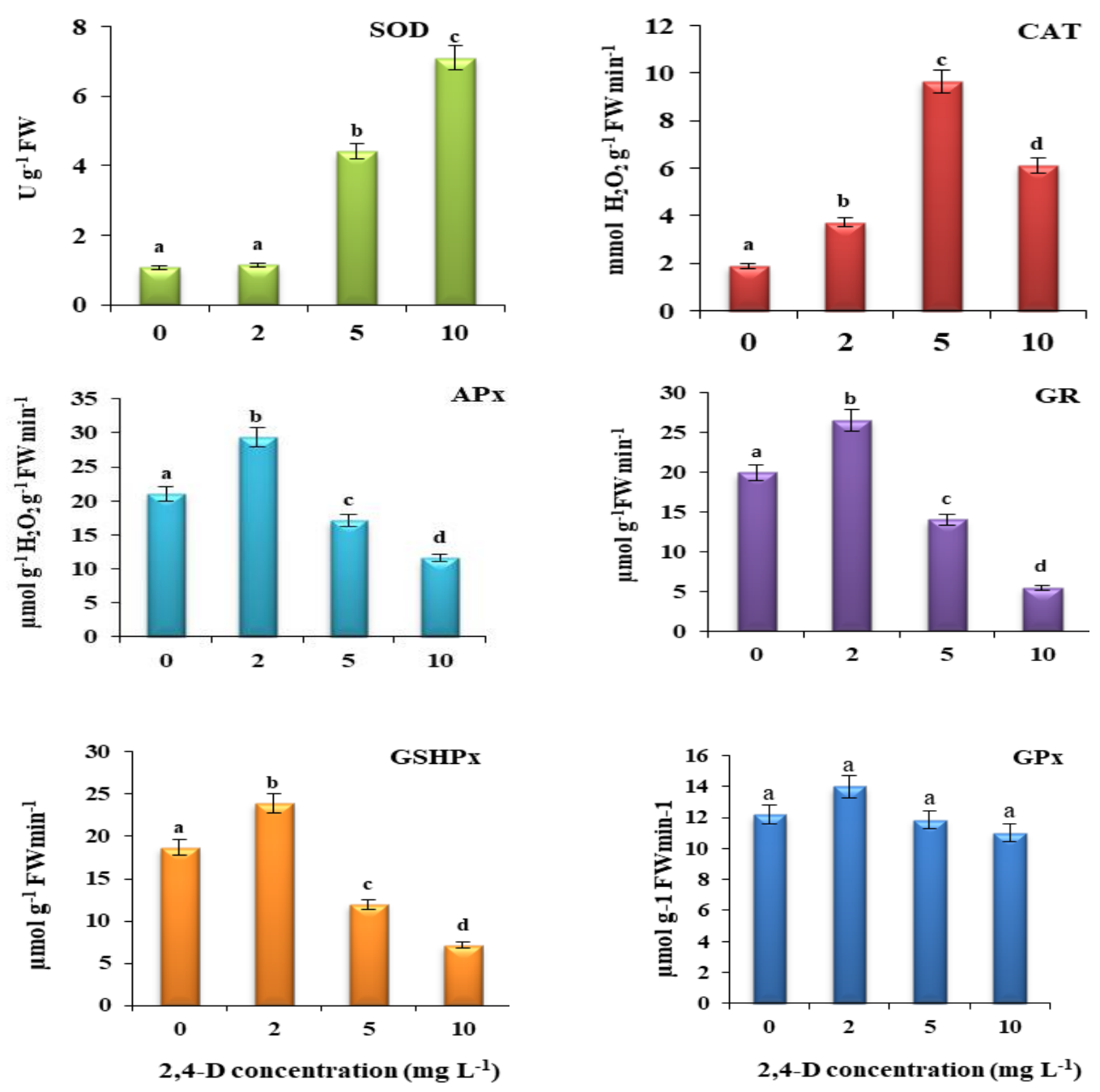

Figure (2): The effect of different concentrations of 2,4-D on activity of antioxidant enzymes; superoxide dismutase (SOD), catalase (CAT), ascorbate peroxidase (APx), guaiacol peroxidase (GPx), glutathione peroxidase (GSHPx) and glutathione reductase (GR) in maize leaves. The vertical bars represent standard deviation of the means of three replicates. Different letters indicates significant differences as evaluated by Duncan's multiple range test.

Table (2): The effect of different concentrations of 2,4-D on NADPH, NADP ${ }^{+}$, NADPH/NADP ${ }^{+}$level and ascorbic acid (AsA) content in maize leaves.

\begin{tabular}{ccccc}
\hline \hline \multirow{2}{*}{$\begin{array}{c}\text { Treatment } \\
\left(\mathbf{m g ~ L}^{-1}\right)\end{array}$} & \multicolumn{2}{c}{ Pyridine Nucleotide levels $\left(\boldsymbol{\mu g} \mathbf{1 0 0 \mathbf { g } ^ { - 1 } \mathbf { F W } )}\right.$} & \multirow{2}{*}{$\begin{array}{c}\text { AsA } \\
\left(\boldsymbol{\mu} \mathbf{m o l ~ g}^{-1} \mathbf{F W}\right)\end{array}$} \\
\cline { 2 - 4 } & $\mathbf{N A D P H}$ & NADP $^{+}$ & NADPH/NADP $^{+}$ & \\
\hline $\mathbf{0}$ & $38.13 \pm 0.33^{\mathrm{a}}$ & $13.95 \pm 0.16^{\mathrm{a}}$ & $2.73 \pm 0.02^{\mathrm{a}}$ & $161 \pm 0.34^{\mathrm{a}}$ \\
$\mathbf{2}$ & $36.79 \pm 0.31^{\mathrm{a}}$ & $14.02 \pm 0.08^{\mathrm{ab}}$ & $2.64 \pm 0.02^{\mathrm{a}}$ & $168 \pm 0.33^{\mathrm{b}}$ \\
$\mathbf{5}$ & $24.15 \pm 0.24^{\mathrm{b}}$ & $18.330 \pm .09^{\mathrm{cd}}$ & $1.32 \pm 0.01^{\mathrm{b}}$ & $152 \pm 0.30^{\mathrm{c}}$ \\
$\mathbf{1 0}$ & $15.99 \pm 0.11^{\mathrm{c}}$ & $21.07 \pm 0.11^{\mathrm{d}}$ & $0.76 \pm 0.01^{\mathrm{c}}$ & $124 \pm 0.33^{\mathrm{c}}$ \\
\hline \hline
\end{tabular}

Values are means \pm SD based on triplicate independent determinations. Different letters indicates significant difference as evaluated by Duncan's multiple range test. 
Table (3): The effect of different concentrations of 2,4-D on the reduced glutathione (GSH), oxidized (GSSG), total (TG) and the ratio of GSH/GSSG forms in maize leaves.

\begin{tabular}{ccccc}
\hline \hline \multirow{2}{*}{$\begin{array}{c}\text { Treatment } \\
\left(\mathbf{m g ~ L} \mathbf{~}^{-1)}\right.\end{array}$} & GSH & GSSG & TG & GSH/GSSG \\
\cline { 2 - 5 } $\mathbf{0}$ & $311 \pm 3.2^{\mathrm{a}}$ & $98 \pm 1.2^{\mathrm{a}}$ & $409 \pm 2.8^{\mathrm{a}}$ & $3.17 \pm 0.02^{\mathrm{a}}$ \\
$\mathbf{2}$ & $296 \pm 2.4^{\mathrm{a}}$ & $102 \pm 1.3^{\mathrm{a}}$ & $398 \pm 1.6^{\mathrm{a}}$ & $2.90 \pm 0.07^{\mathrm{a}}$ \\
$\mathbf{5}$ & $185 \pm 1.2^{\mathrm{b}}$ & $121 \pm 1.6^{\mathrm{b}}$ & $306 \pm 1.4^{\mathrm{b}}$ & $1.53 \pm 0.01^{\mathrm{b}}$ \\
$\mathbf{1 0}$ & $136 \pm 1.4^{\mathrm{c}}$ & $159 \pm 1.4^{\mathrm{c}}$ & $295 \pm 1.8^{\mathrm{b}}$ & $0.86 \pm 0.01^{\mathrm{c}}$ \\
\hline \hline
\end{tabular}

Values are means \pm SD based on triplicate independent determinations. Different letters means significant difference as evaluated by Duncan's multiple range test.

\section{Glucose-6-phosphate dehydrogenase activity}

Data in Figure 3 revealed that the activity of G6PDH increased significantly upon spraying with different concentrations of 2,4-D herbicide in a dosage contingent manner. The increase of G6PDH activity, in $5 \mathrm{mg} \mathrm{L}-1$ and $10 \mathrm{mg}$ L-1 2,4-D, recorded 2.6-and 4.3-fold of control, respectively.

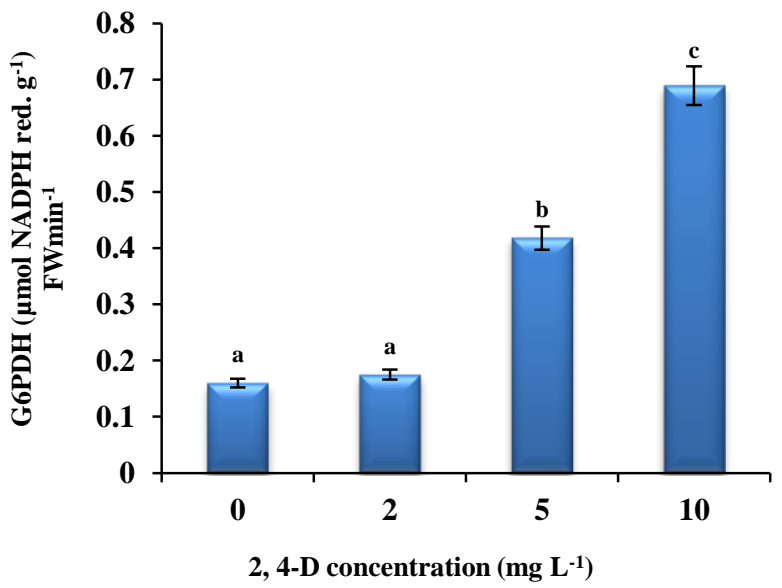

Figure (3): The effect of different concentrations of 2, 4-D on glucose-6-phosphate dehydrogenase (G6PDH) in maize leaves. Values are means \pm SD based on triplicate independent determinations. Different letters indicates significant difference as evaluated by Duncan's multiple range test.

\section{DISCUSSION}

Foliar application of low dose $\left(2 \mathrm{mg} \mathrm{L}^{-1}\right)$ of $2,4-\mathrm{D}$ significantly increased the fresh and dry biomasses of 28-day old maize leaves, compared to control, possibly through promoting the growth similar to IAA phytohormone. In accordance with these observations, Xu et al., (2013) mentioned that low doses of 2,4-D can act as growth hormone promoting cell division and elongation (as the role of IAA in induction of the growth). Conversely, high 2, 4-D concentrations markedly reduced the growth of maize leaves. These findings might be attributed to generation and accumulation of ROS which are doable for induction of the oxidative damage of the cellular components. The current study clearly demonstrated that there was a significant increase of $\mathrm{H}_{2} \mathrm{O}_{2}$ and MDA accumulation in highly 2,4-D-sprayed maize leaves, in comparison to control. Cobb and Reade (2010) and Grossmann (2010) reported that some phytotoxicity of herbicides may be related to the generation of ROS and induction of oxidative damage of cellular components as well as accumulation of ABA and ethylene. Thus, the supperssion in growth of 2,4-D-treated maize leaves might be related to enhancement of the $\mathrm{ABA}$ and ethylene which induce senescence and imbalance of endogenous auxins as well as promoting oxidative damage of plasma membranes and cellular components (Christoffoleti et al., 2015).

Although low 2,4-D concentration insignificantly changed the photosynthetic parameters content, while the high concentrations significantly declined the pigments content and quantum yield of PSII (Fv/Fm) values. These observations were accompanied with generation of $\mathrm{H}_{2} \mathrm{O}_{2}$ and MDA which might reveal the enhancement of oxidative stress of chloroplasts and thylakoid membranes, degradation of pigments and some photosynthetic enzymes and blocking electron transport of PSII. These findings were in accordance with those reported for several plant species such as Scenedesmus quadricauda (Wong, 2000), Oryza sativa (Wu et al., 2010) and wheat (Agostinetto et al., 2016). Therefore the reduction of FW and DW in 2, 4-Dtreated maize leaves might be attributed also to disorder of the photosynthetic machinery. In accordance with our results, Karuppanapandian et al., (2011) and Islam et al., (2018) reported that 2, 4-D stimulated oxidative stress symptoms and reduced biomass in mung bean and rice plants owing to the degradation of the synthesis of chlorophyll and DNA.

It has been reported that the activation of ROSgenerating oxidases including xanthine oxidase, acylCoA oxidase, plasma membranes-associated $\mathrm{NADPH}_{2}$ oxidase and lypoxygenase localized in chloroplasts and peroxisomes (McCarthy-Suarez et al., 2011; Siebers et al., 2016).Thus, the generation of $\mathrm{H}_{2} \mathrm{O}_{2}$ and MDA in 2,4-D-sprayed maize leaves, in this study, might be attributed to the enhancement of these cytoplasmic organelles-associated oxidases causing the oxidative stress, and hence led to the chlorosis, senescence and death of maize leaves. It is well known that the gener- 
ation of ROS required homeostasis equilibrium between the activity of the ROS-generating and the ROSscavenging enzymatic and non-enzymatic systems (McCarthy-Suarez et al., 2011; Nohatto et al., 2016).

There was a significant increase of SOD and CAT activities in maize leaves under high 2, 4-D dose, comparing to the control. Similarly, several studies have been recorded the enhancement of SOD and CAT activities in various plant organs under herbicide treatments (Zhang et al., 2014; Caverzan et al., 2019). Conversely, Laxmi et al., (2018) showed a significant decline in field and in vitro grown shoots of Portulaca oleracea under 2, 4-D treatment. Pazmino et al., (2011) stated that, foliar application of 2, 4-D herbicide resulted in a marked upregulation of SOD and CAT activities.

It has been shown that application of phenoxy acetic acid members and other herbicide families markedly inhibited peroxidases activity in a number of plants (Boulahia et al., 2016; Harre et al., 2018). Compared to the control, APx and GSHPx activities were drastically declined in maize leaves sprayed with 5 and $10 \mathrm{mg} \mathrm{L}{ }^{-1}$ 2, 4-D. Moreover, GPx activity was insignificantly changed in the high 2, 4-D dose-applied maize leaves revealing insufficient scavenging of generated $\mathrm{H}_{2} \mathrm{O}_{2}$. These findings were accompanied by significant increase of $\mathrm{H}_{2} \mathrm{O}_{2}$ content which indicate the collapses of ROS-scavenging systems, and hence disorder of cellular redox homestasis in maize leaves.

Yang et al., (2014) suggested that under stress conditions G6PDH activity is markedly induced for production of NADPH which is involving as a cofactor for several enzymes. Foyer and Noctor (2005) reported that GR-NADPH reduces oxidizing glutathione form to reduced form which introduces directly in the reduction of $\mathrm{H}_{2} \mathrm{O}_{2}$ in presence of GSHPx and GST enzymes or indirectly via AsA-GSH cycle. Although application of 2,4-D resulted in a significant increase G6PDH activity in maize leaves, it significantly declined GR and both GSH and AsA contents. These observations were associated with a significant accumulation of $\mathrm{H}_{2} \mathrm{O}_{2}$ and might reveal the competition between GR and NADPH-oxidases on the $\mathrm{NADPH}_{2}$ as a reducing agent for GSSG to GSH or $\mathrm{O}^{-}$to $\mathrm{H}_{2} \mathrm{O}_{2}$. In addition, the decline of GSH content might result in the indirect suppression of AsA-GSH cycle and direct elimination of generated $\mathrm{H}_{2} \mathrm{O}_{2}$.

It is well known that the ratio of AsA/DHAsA, NAD (P)H/NADP and GSH/GSSG controls the cellular redox homeostasis (Gill et al., 2013). In this work, there was a significant decline of GSH and NADPH contents in 2, 4-D- treated maize leaves, and that might be related to decrease of GR activity and increase of plasma membranes-associated NADPH oxidase activity. Moreover, the decrease in both GSH and NADPH was accompanied with a marked decline of GSH/GSSG and NADPH/NADP ${ }^{+}$redox state and induction of ROS generation which indicated a disturbance of cellular redox homeostasis and induction of oxidative damage, and hence leaf death.

\section{CONCLUSION}

The outcomes of this investigation can suggest that spraying maize leaves with low doses of 2,4-D can act as growth hormone stimulator, whereas high doses alter the cellular homeostasis and elicit the response of the enzymatic antioxidant systems. The disturbance of the antioxidative activities and imbalance of the cellular redox potential leading to enhancement of oxidative damage of cellular components, and hence reduce the growth. ROS overproduction might be considered as the key in the effect of 2, 4-D and may have differential roles in senescence and cell death.

\section{REFERENCES}

AGOSTINETTO, D., L.T. PERBONI, A.C. LANGARO, J. GOMES, D.S. FRAGA AND J.J. FRANCO. 2016. Changes in photosynthesis and oxidative stress in wheat plants submitted to herbicides application. Planta Daninha Viçosa-MG, 34(1): 1-9.

BOOMINATHAN, R. AND P.M. DORAN. 2002. Ni induced oxidative stress in roots of the $\mathrm{Ni}$ hyper accumulator, Alyssum bertolonii. New Phytologist, 156: 205-215.

BOULAHIA K., P. CAROL, S. PLANCHAIS AND O. ABROUS-BELBACHIR. 2016. Phaseolus vulgaris L. seedlings exposed to prometryn herbicide contaminated soil trigger an oxidative stress response. Journal of Agricultural and Food Chemistry, 64: 3150-3160.

BRANQUINHO, C., D.H. BROWN AND F. CATARINO. 1997. The cellular location of $\mathrm{Cu}$ in lichens and its effect on membrane integrity and chlorophyll fluorescence. Environmental and Experimental Botany, 38: 165-179.

BUEGE, J.A. AND S.D. AUST. 1978. Microsomal lipid peroxidation. Methods in Enzymology, 52: 302-310.

CARUSO, R., J. CAMPOLO, C. DELLANOCE, R. MARIELE, O. PARODI AND R. ACCINNI. 2004. Critical study of pre-analytical and analytical phases of adenine and pyridine nucleotide assay in human whole blood. Analytical Biochemistry, 330: 43-51.

CAVERZAN, A., C. PIASECKI, G. C. CHAVARRIA GERALDO, JR. N. STEWART AND L. VARGAS. 2019. Defenses against ROS in crops and weeds: The Effects of Interference and Herbicides. International Journal of Molecular Sciences, 20: 1086; doi:10.3390/ijms20051086.

CHRISTOFFOLETI, P.J., M.R. ALVES DE FIGUEIREDO, L.E. PEREIRA PERES, S. NISSEN AND T. GAINES. 2015. Auxinic herbicides, mechanisms of action, and weed resistance: A look into recent plant science advances. Scientia Agricola, 72 (4): 356-362.

COBB, A.H. AND J.P. READE. 2010. Auxin-type herbicides. PP 133-156 in Herbicides and Plant Physiology. $2^{\text {nd }}$ edn. New York, NY: John Wiley \& Sons. 
CORPAS, F.J. AND J.B. BARROSO. 2018. Peroxisomal plant metabolism an update on nitric oxide, $\mathrm{Ca} 2 \mathrm{C}$ and the NADPH recycling network. Journal of Cell Science, 131:jcs202978.DOI 10.1242-/jcs.202978.

CZARNOCKA, W. AND S. KARPINSKI. 2018: Friend or foe? Reactive oxygen species production, scavenging and signalling in plant response to environmental stresses. Free Radical Biology and Medicine, 122:4-20.

ELIA, A.C., R.GALARINI, M.I. TATICCHI, A.J.M. DORR, AND L. MANTILACCI. 2003. Antioxidant responses and bioaccumulation in Ictalurus melas under mercury exposure. Ecotoxicology and Environmental Safety 55: 162-167.

FOYER, C.H. AND G. NOCTOR. 2005. Oxidant and antioxidant signalling in plants: a re-evaluation of the concept of oxidative stress in a physiological context. Plant Cell and Environment, 28: 10561071.

GIANNOPOLITIS, C.N. AND S.K. RIES. 1977. Superoxide dismutase: II. Purification and quantitative relationship with water-soluble protein in seedlings. Plant Physiology, 59(2): 315-318.

GILL, S.S. AND N.TUTEJ A. 2010. Reactive oxygen species and antioxidant machinery in abiotic stresses tolerance in crop plants. Plant Physiology and Biochemistry, 48:909-930.

GILL, S.S., N.A. ANJUM, M. HASANUZZAMAN, R. GILL, D.K. TRIVEDI, I. AHMAD, E. PEREIRA AND N. TUTEJA. 2013. Glutathione and glutathione reductase: a boon in disguise for plant abiotic stress defense operations. Plant Physiology and Biochemistry, 70: 204-212.

GOGGIN, D.E., G.R. CAWTHRAY AND S.B. POWLES. 2016. 2,4-D resistance in wild radish: reduced herbicide translocation via inhibition of cellular transport. Journal of Experimental Bototany, 67: 3223-3235.

GOLDBERG, D.M. AND R.J. SPOONER 1983. In Methods of Enzymatic Analysis (Bergmeyen, H.V. Ed.) $3^{\text {rd }}$ edn. Vol 3, pp 258 - 265, Verlog Chemie, Deerfield beach, FI.

GOSSETT, D.R., E.P. MILLHOLLON AND C. LUCAS. 1994. Antioxidant reponse to $\mathrm{NaCl}$ stress in salt-tolerant and salt-sensitive cultivars of cotton. Crop Science, 34: 706-714.

GRIFFITH, O.W. 1985. Glutathione and glutathione disulphide. In: Bergmeyer HU ed. Methods of Enzymatic Analysis. Weinheim, Verlagsgesellschaft mbH. 521-529.

GROSSMANN, K. 2010. Auxin herbicides: current status of mechanism and mode of action. Pest Management Science, 66: 113-120.

HARRE, N.T., H. NIE, Y. JIANG And B.G. YOUNG. 2018. Differential antioxidant enzyme activity in rapid-response glyphosate-resistant Ambrosia trifida. Pest Management Science, 74: 2125-2132.

HOAGLAND, D.R. AND D.I. ARNON. 1950. The water culture method for growing plants without soil. California Agricultural Experimental Station Circular, 347:1-32. Berkeley: University of California.

ISLAM, F., M.A. FAROOQ, R.A. GILL, J. WANG, C. YANG, B. ALI AND W.J. ZHOU. 2017. 2,4-D attenuates salinity-induced toxicity by mediating anatomical changes, antioxidant capacity and cation transporters in the roots of rice cultivars. Science Report, 7: 10443.

ISLAMA, F., J. WANGA, A. MUHAMMAD, H. FAROOQA, S.S. MUHAMMAD, X. L. KHANA J. ZHUA, M.ZHAOD, S. MUÑOSE, X. QING AND L.W. ZHOUA. 2018. Potential impact of the herbicide 2,4-dichlorophenoxyacetic acid on human and ecosystems. Environment International, 111: 332-351.

KARUPPANAPANDIAN, T., H.W. WANG, N. PRABAKARAN, K. JEYALAKSHMI, M. KWON, K. MANOHARAN AND W. KIM. 2011. 2,4-dichlorophenoxyacetic acid-induced leaf senescence in mung bean (Vigna radiata L. Wilczek) and senescence inhibition by cotreatment with silver nanoparticles. Plant Physiology and Biochemistry, 49: 168-177.

KRUSE, N.D., R.A. VIDAL, C. DALMAZ, M.M. TREZZI AND I. SIQUEIRA. 2006. Estresse oxidativo em girassol (Helianthus annuus) indica sinergismo para a mistura dos herbicidas metribuzin e clomazone. Planta Daninha, Viçosa, 24(2): 379-390.

LAXMI, S., M.R. CHAMBHARE, S. KADLAG, M.L. AHIRE AND T.D. NIKAM. 2018. Herbicide effects on pigments and antioxidant enzymes of Portulaca oleracea L. Journal of Pharmacognosy and Phytochemistry, 7(1): 2024-2031.

MCCARTHY-SUÁREZ, I., M. GÓMEZ, L.A. DEL RÍO AND J.M. PALMA. 2011. Role of peroxisomes in the oxidative injury induced by the auxin herbicide 2,4-D in leaves of pea plants. Biologia Plantarum, 55: 485-492.

MORAN, R. AND D. PORATH, 1980. Chlorophyll determination in intact tissues using N,N-dimethyl formamide. Plant Physiology, 65: 478-487.

NOCTOR, G. AND C.H. FOYER.1998. Ascorbate and glutathione: keeping active oxygen under control. Annual Review of Plant Physiology and Plant Molecular Biology, 49: 249-279.

NOHATTO, M.A., D. AGOSTINETTO, A.C. LANGARO, C. DE OLIVEIRA AND Q. RUCHEL. 2016. Antioxidant activity of rice plants sprayed with herbicides. Pesquisa Agropecuária Tropical, Goiânia, 46(1): 28-34.

PAZMIÑO, D.M., M. RODRÍGUEZ-SERRANO, M.C. ROMERO-PUERTAS, A. ARCHILLARUIZ, L.A. DEL RÍO AND L.M.SANDALIO. 2011. Differential response of young and adult leaves to herbicide 2,4-dichlorophenoxyacetic acid in pea plants: role of reactive oxygen species. Plant Cell and Environment, 34:1874-89. 
PAZMIÑO, D.M., M.C. ROMERO-PUERTAS AND L.M. SANDALIO. 2012. Insights into the toxicity mechanism of and cell response to the herbicide 2,4-D in plants. Plant Signaling and Behaviour, 7: $1-3$.

SAMIR, R., T. ESSAM, Y. RAGAB AND A. HASHEM. 2015. Enhanced photocatalyticbiological degradation of 2,4-dichlorophenoxy acetic acid. Bulletin of Faculty of Pharmacy, Cairo University, 53: 77-83.

SERGIEV, I., V. ALEXIEVA AND E. KARANOV. 1997. Effect of spermine, atrazine and combination between them on some endogenous protective systems and stress markers in plants. Comptes Rendus de l'Academie Bulgare des Science, 51(3): 121-124.

SGHERRI, C., M.F. QUARTACCI, R. IZZOAND AND F. NAVARI-IZZO. 2002. Relation between lipoic acid and cell redox status in wheat grown in excess copper. Plant Physiology and Biochemistry, 40(6-8):591-597.

SIEBERS, M., M. BRANDS, V. WEWER, Y. DUAN, G. HÖLZL AND P. DÖRMANN 2016. Lipids in plant-microbe interactions. Biochimica et Biophysica Acta, 1861: 1379-1395.

SKIBA, E. AND W.M. WOLF. 2017. Commercial phenoxyacetic herbicides control heavy metal uptake by wheat in a divergent way than pure active substances alone. Environmental Science Europe, 29(1):26-36.

SOKAL, R., R. AND AND F.J. ROHLF. 1995. "Biometry: The Principles and Practice of Statistics in Biological Research". Freeman, W.H., Company, New York, USA, 271-356.

URBANEK, H., E. KUZNIAK-GEBAROWSKA AND K. HERKA. 1991. Elicitation of defense responses in bean leaves by Botrytis cinerea polygalacturonase. Acta Physiolgica Plantarum, 13: 43-50.

WANG, X., M. RUAN, Q. WAN , W. HE, L.YANG, X. LIU, L. HE, L. YAN AND Y. BI. 2019. Nitric oxide and hydrogen peroxide increase glucose-6-phosphatedehydrogenase activities and expression upon drought stress in soybean roots. Plant Cell Reports, https://doi.org/10.1007/s00299. 019-02473-3.

WELLBURN, A.R. 1994. The spectral determination of chlorophyll a and b, as well as total carotenoids, using various solvents with spectrophotometers of different resolution. Journal of Plant Physiology, 144: 307-313.

WONG, P.K. 2000. Effects of 2,4-D, glyphosate and paraquat on growth, photosynthesis and chlorophyll-a synthesis of Scenedesmus quadricauda Berb 614. Chemosphere, 41:177-82.

WU, G.L., J. CUI, L.TAO, H. YANG. 2010. Fluroxypyr triggers oxidative damage by producing superoxide and hydrogen peroxide in rice (Oryza sativa). Ecotoxicology, 19 (2):124-132.

XU, Z., C. ZHANG, X. ZHANG, C. LIU, Z. WU, Z.YANG, K.ZHOU, X. YANG AND F. LI. 2013. Transcriptome profiling reveals auxin and cytokinin regulating somatic embryogenesis in different sister lines of cotton cultivar CCRI24. Journal of Integrative Plant Biology, 55: 631-642.

YANG, Y., Z. FU, Y. SU, X. ZHANG, G. LI, J. GUO, Y. QUE AND L.XU. 2014. A cytosolic glucose-6phosphate dehydrogenase gene, ScG6PDH, plays a positive role in response to various abiotic stresses in sugarcane. Science Report, 4:7090; DOI:10.1038/srep07090.

ZABALOY, M.C. AND M.A. GÓMEZ. 2014. Isolation and characterization of indigenous 2,4-D herbicide degrading bacteria from an agricultural soil in proximity of Sauce Grande River, Argentina. Annals of Microbiology, 64: 969-974.

ZHANG, F. AND M.B. KIRKHAM. 1996. Antioxidant responses to drought in sunflower and sorghum seedlings. New Phytologist, 132:361-373.

ZHANG, H., Y. JIANG, Z. HE AND M. MA. 2005: Cadmium accumulation and oxidative burst in garlic (Allium sativum). Journal of Plant Physiology, 162(9): 977-984.

ZHANG, J.J., LU, Y.C. ZHANG, J.J. TAN, L.R. AND H. YANG. (2014). Accumulation and toxicological response of atrazine in rice crops. Ecotoxicology and Environmental Safety, 102 (2):105-112. 


\title{
تأثير 4,2-ثنائى كلوروفينوكسي حمض الخليك على أنظمة مضادات الأكسدة فى نبات غير مستهدف ( نبات الذرة)
}

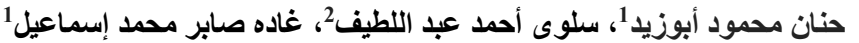

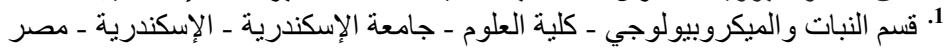

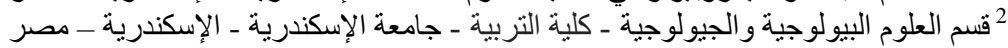

الملخص العربــــي

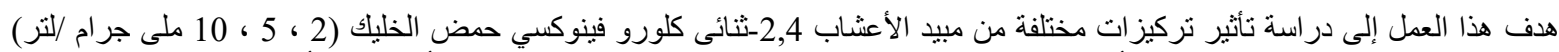

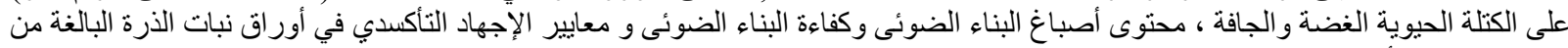

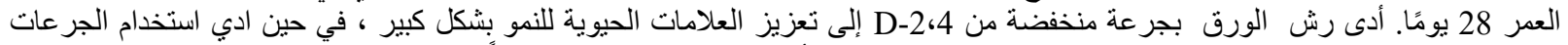

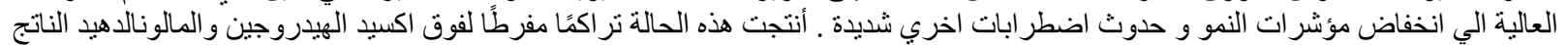

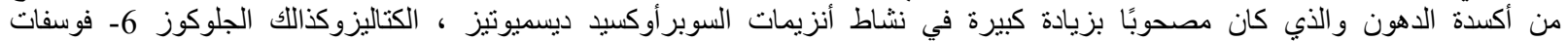

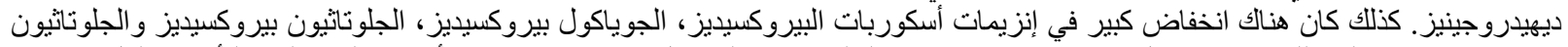

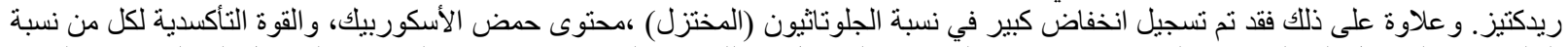

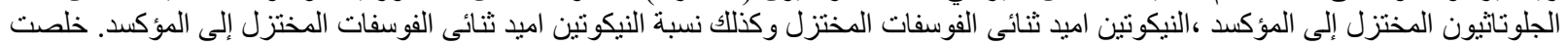
الدر اسة إلى أن استخدام الجر عات العالية من 4، -2 ربما تتسبب في تهديد النباتات الغير المستهدفة من خلال اضطر اب النئ الأنظمة المضادة للأكسدة. 